\title{
COVID-19 and kidney injury: Could Renin-Angiotensin com- ponents crosstalk with immune responses?
}

\author{
Bernard Nsengimana ${ }^{1,2}$, Yu Jin ${ }^{1,2}$, Yuting Jia ${ }^{1,2}$, Wenqiang Wei ${ }^{1,2,3, *}$, Shaoping Ji ${ }^{1,2, *}$ \\ Cell signal transduction Laboratory and Institute of Biomedical Informatics, School of Basic Medical \\ Sciences, Henan University, Kaifeng 475000, China \\ 2 Henan Provincial Engineering Centre for Tumor Molecular Medicine, Kaifeng 475000, China \\ Kaifeng Key Laboratory of Infection and Biosafety, Henan University, Kaifeng 475004, China \\ * Correspondence: Wenqiang Wei, School of Basic Medical Sciences, Henan University, Kaifeng, China; Tel: \\ 86-037123880585; Fax: 86-0371-23880585; E-mail: weiwq@henu.edu.cn; Shaoping Ji, School of Basic Medical \\ Sciences, Henan University, Kaifeng, China; Tel: 86-0371-23880585; Fax: 86-0371-23880585; E-mail: \\ shaopingji@henu.edu.cn
}

\begin{abstract}
Coronavirus disease 2019 (COVID-19) is a global pandemic caused by severe acute respiratory syndrome coronavirus 2 (SARS-CoV-2). To contain the virus, numerous preventive measures have been taken including isolation of patients, careful infection control, social distancing, and taking vaccine. So far, new confirmed and death cases are still increasing. SARS-CoV-2 invades cells by using the angiotensin converting enzyme 2 (ACE2). ACE2 is an essential enzyme of the renin-angiotensin system (RAS) which converts angiotensin II (Ang II) to angiotensin (1-7). ACE2 is expressed in different organs, including lung, heart, and kidney. A high number of COVID-19 patients developed kidney injury has been reported. Renal impairment and acute injury are associated with mortality of COVID-19, which is 14-16 times higher than other general patients. Acute Kidney Injury has been occured in 2.9 up to $43 \%$ of intensive care unit patients. The increasing evidence show that the components of RAS can activate the complement cascade, and cytokines production. Kidney injury caused by SARS-CoV-2 is related mainly to systemic and local inflammation. Moreover, the uncontrolled immune responses mediated by SARS-CoV-2 including hypercytokinaemia, secondary hemophagocytic lymphohistiocytosis, antibody dependent enhancement, complement system, and phagocytic cells activation can contribute in the virus pathogenesis leading to associated renal dysfunction. However, the role and crosstalk between of RAS components and immune response in mediating kidney injury remain undefined. In this review, we focus on the recent studies to provide the pathogenesis of SARS-CoV-2 interacting with RAS and immune responses to mediate kidney injury.
\end{abstract}

Keywords: SARS-CoV-2; RAS; acute kidney injury; immune response

\section{Introduction}

Coronavirus disease 2019 (COVID-19) is a global pandemic and its impact on human has been immense. To contain the virus, numerous preventive measures have been taken such as isolation of patients, careful infection control, social distancing, and taking vaccine. So far, new confirmed and death cases are still increasing.

SARS-CoV-2 gets access to the human body, mainly via the upper respiratory tract and invades the target organs like the lower respiratory tract. Moreover, it may circulate in the peripheral blood stream to invade other organs via ACE2 receptors [1]. After infecting the lungs, it stimulates the local immune responses such as the recruitment of inflammatory cells, including macrophages and monocytes. It has been reported that phagocytic cells correlate with the lung damage in critically COVID-19 patients, and also the acute respiratory illness with diffuse alveolar hemorrhage and acute respiratory failure are the early character of COVID-19 [2]. The immune responses usually have the capability of clearing the infected cells, and producing the antibodies which inactivate the virus. 
However, a dysregulation of immune responses can lead to the local and systemic pathology due to systemic cytokine storms. Hence, SARS-CoV-2 causes the other organs injury by activating the overproduction immune responses, which may eventually increase the morbidity and mortality of COVID-19. In this review, we focus on kidney injury caused by SARS-CoV-2.

\section{Pathogenesis of SARS-CoV-2 in kidney}

Kidney injury caused by SARS-CoV-2 may be related to the systemic and local inflammation. Different studies of immunological data for patients with COVID-19 revealing that the increased cytokines can mediate the hyper-inflammatory responses which can contribute a lot in amplifying acute kidney injury (AKI) as summarized in Table 1. The kidney histology from autopsies of COVID-19 shows the severe acute tubular necrosis with lymphocyte and macrophage infiltration, clotting and disseminated intravascular coagulation with small vessel thrombosis [3]. Uncontrolled pro-coagulation factors and complement system are known to activate each other which can intensify the pathogenesis of SARS-CoV-2 in kidney by inducing the inflammatory mediators [4]. Renal impairment and acute injury have been documented to be associated with mortality of COVID-19, which is 14-16 times higher than other general patients [5]. It is known that renal impairment is associated with hematuria, proteinuria, and higher creatinine due to kidney cell injury and these features have been reported in COVID-19 patients. A consecutive study of 701 COVID-19 patients in Wuhan, China reported that $43.9 \%$ of patients had proteinuria, 26.7\% had hematuria [6]. AKI has been reported as a significant complication of the COVIV-19 to occur in 2.9 up to $43 \%$ of intensive care unit patients [7]. Another study of 5,449 COVID-19 patients found that AKI patients developed at the rate of $36.6 \%$ were 35\% died and 14.3-20\% required renal replacement therapy (RRT) [8]. Moreover, a recent observational study carried out in a tertiary care hospital in Milan, Italy shows that among 99 patients, 75\% developed AKI [9].

AKI process was suspected to be associated with the systemic circulation of SARSCoV-2 as it was detected in urine samples of patients with COVID-19 [10]. Also, the residues of SARS-CoV-2 nucleocapsid protein were found in the kidney tubules and its clusters particles were found in tubular epithelium and podocytes [11]. However, Kudose et al., did not get a great evidence of a direct SARS-CoV-2 invasion in AKI [12]. Another recent study has been carried out on COVID-19 patients with AKI shows the acute tubular necrosis, but found no evidence of virus particles in kidney biopsy [13]. Totally, although the kidneys are not highly exposed to SARS-CoV-2 invasion compared to the lungs, the virus might mediate AKI in multiple mechanisms such as a direct invasion, and the intervention of cytokine production. 
Table 1. Features of immune responses in COVID-19 patients.

\begin{tabular}{|c|c|c|c|}
\hline Methodology of the study. & Results & Conclusion & Reference \\
\hline $\begin{array}{l}\text { A retrospective study analyzed } \\
\text { clinical and laboratory data of } \\
88 \text { hospitalization patients with } \\
\text { COVID-19 }\end{array}$ & $\begin{array}{c}\text { In critically patients, } 86 \% \text { have } \\
\text { Lymphopenia, above } 70 \% \text { have } \\
\text { increased IL-2R, IL- } 6 \text { and TNF- } \\
\alpha\end{array}$ & $\begin{array}{c}\text { Inflammatory cytokines may } \\
\text { correlate with severity of a } \\
\text { disease }\end{array}$ & (Xu et al., 2020) [60] \\
\hline $\begin{array}{l}\text { Clinical and immunologic data } \\
\text { were analyzed in } 71 \text { patients } \\
\text { with COVID-19 }\end{array}$ & $\begin{array}{l}\text { Natural killer cells, complement } \\
\text { C1q, T and B lymphocytes, } \\
\text { cells were reduced while IL-6, } \\
\text { neutrophils, CRP were } \\
\text { increased }\end{array}$ & $\begin{array}{l}\text { Dysregulation of immune } \\
\text { response and pro-inflammatory } \\
\text { cytokines may contribute to the } \\
\text { cytokine storms }\end{array}$ & (Wu et al., 2020) [53] \\
\hline $\begin{array}{l}\text { Clinical and immunologic } \\
\text { markers were analyzed in } \\
\text { retrospective study of } 21 \\
\text { patients with COVID-19 }\end{array}$ & $\begin{array}{l}\text { Absolute number of CD4 and } \\
\text { CD8 T cells were reduced while } \\
\text { IL-2R, IL- } 6 \text {, and TNF- } \alpha \text { were } \\
\text { increased }\end{array}$ & $\begin{array}{l}\text { A reduction of } \mathrm{T} \text { lymphocytes } \\
\text { may result in severity of a } \\
\text { disease }\end{array}$ & (Chen et al., 2020) [54] \\
\hline $\begin{array}{l}\text { A study analyzed the plasma } \\
\text { cytokines of } 53 \text { patients with } \\
\text { COVID-19 }\end{array}$ & $\begin{array}{l}\text { IL-1, IL-7, IL-10, GSFC, IP-10, } \\
\text { MCP-3, IFN- } \gamma \text {, IL-2, IL-18, } \\
\text { and MIP1A were increased in } \\
\text { patients compared to the healthy } \\
\text { control } \\
\end{array}$ & $\begin{array}{l}\text { SARS-CoV-2 can stimulate the } \\
\text { cytokines release which } \\
\text { intensify the severity of a } \\
\text { disease }\end{array}$ & (Yang et al., 2020) [55] \\
\hline
\end{tabular}

\section{Mechanisms of acute kidney injury caused by SARS-CoV-2}

The AKI caused by SARS-CoV-2 is mediated by several factors, we review the possible multi-factorials underlying mechanisms of acute kidney injury include a direct viral toxicity, immune pathology (Fig. 1)

\section{Cytopathic effects}

The evidence shows that nsp10 of SARS-CoV interacts with cytochrome oxidase and NADH $4 \mathrm{~L}$ to disturb the normal functioning of mitochondria thereby causing cell injury [14]. In addition, a recent report shows that SARS-CoV-2 in type II alveolar pneumocytes induces focal lung injury, a cytopathic effect [15]. Similar evidence shows that SARS-CoV2 invades directly human kidney cells include proximal tubular epithelial cells (PTEC) where viral replication may result in a cytopathic effect [16]. Thus, SARS-CoV-2 can infect PTEC, glomerular mesangial cells, and glomerular epithelial cells (podocytes) which exhibit its AC2 receptor to induce AKI by direct cytopathogenic effects. However, an extent of a direct infection to mediate kidney pathology remains unknown.

\section{Immune response and SARS-CoV-2: PAMP in the pathogenesis of SARS-COV-2}

Immune cells like phagocytic cells are activated through their ability of recognizing the pathogen-associated molecular patterns (PAMP) including unmethylated doublestranded DNA (CpG), single stranded RNA, flagellin, lipoproteins and lipopolysaccharides of pathogens using PRR on the cell membrane [17]. PAMP and their carboxyl-terminal domain interact with Toll/interleukin-1 Receptor (TIR) -containing adaptors leading to activation of a downstream signal transduction [18]. Recognition of viral PAMPs by TLRs on macrophages activates the innate immune response by recruiting signal transfer proteins such as MyD88, TRAM, TRIF in the cytoplasmic TIR domain followed by phosphorylation of different kinases including IRAKs, TBK1, and IKKs and tumor necrosis factor receptor-related factor-6 (TRAF-6) according to the different adaptors, eventually lead to activation of the NF- $\kappa B$, MAPK, PI3K, JNK, STAT, interferon (IFN) pathways that promote the transcription of inflammatory cytokines including IFN, IL-1 $\beta$, IL-6, and others which coordinate the local and systemic inflammatory responses [19]. It has been reported that TLRs play a great role in recognizing SARS-CoV infection where TRAM -/-, TLR3-/- and TRL4-/- mice were at risk to be affected by SARS-CoV than wild mouse counterpart [20]. SARS-CoV S protein has been documented to stimulate the immune 
responses through the activation of NF- $\kappa$ B pathway. The interaction between SARS-CoV2 proteins with TLRs is a worth studying in the future.

\section{SARS-CoV-2 and Cytokines}

The effect of IFN production involves in activating the immune cells like CD8+ cytotoxic T which detects the viral peptides displayed on class I major histocompatibility complex (MHC-I) proteins and lyses the infected cells, followed with the elevation of CD4+T cells which detects the viral peptides on MHC-II of macrophages. B lymphocytes can be stimulated and crosstalk with CD4+T cells, leading in the production of IgM and IgG antibodies [21]. The current study shows that the severity of COVID-19 is associated with lymphopenia [22]. Morbidity and mortality of SARS-CoV- 2 patients can be associated with a decreased level of white blood cells and lymphocytes count in COVID-19. The pathway mediated by SARS-CoV-2 to induce the apoptosis of T cells remains unclear. Interestingly, another study demonstrated that even the number of CD4+ and CD8+T cells in the peripheral blood are reduced, but that these cells are highly activated and also correlate with increased levels of CD4+ T cytokines, INF- $\gamma$, TNF- $\alpha$, IL-2, and IL-17 in COVID19 patients compared to the control group [23]. COVID-19 patients admitted in ICU compared to non-ICU had higher concentration of cytokines, including MIP1A, TNF- $\alpha$, IL-2, IP-10, GSCF, and MCP-1 [24]. The production of cytokines is beneficial as they can recruit the inflammatory cells, however, upregulation and overproduction of cytokines such as IL-1 $\beta$, TNF, and IL-6 mediates an acute generalized inflammatory response resulting in septic shock [24]. Several studies have determined the role of different cytokines in AKI where IFN- $\gamma$, IL-6, and MCP-1 have been associated with AKI due to Th1 and Th2 activation in animal models of ischemic-reperfusion injury (IRI) [26] and Tumor necrosis factor like weak inducer of apoptosis (TWEAK) has been participating in renal tubular cell injury [27]. IL-6 receptor blocker (Tocilizumab) and IL-1 antagonist have been proposed to weaken the hyper-inflammation induced by SARS-CoV-2 [28].However, the virus adapts several ways of escaping the immune response as type I and III interferon responses has been documented to be suppressed in SARS [29] and anti-Spike antibodies urged the excessive inflammatory factor production, including IL-8, IL-6, IL-1 $\beta$, and TNF by human M2 macrophages, which subsequently disrupt the endothelial barrier membrane integrity and mediates microvascular thrombosis in severe cases of COVID-19 [30]. More increasing evidences show that SARS-CoV-2 can evade immune responses and induce hyperinflammatory responses. The systematic inflammation can induce the Kidney impairment. However, the mechanism of immune evasion used by SARS-CoV-2 remains unclear.

\section{SARS-CoV-2 and sHLH}

The secondary hemophagocytic lymphohistiocytosis (sHLH) refers to the immune cells that become overactive and T helper cells trigger too much inflammatory cytokines while macrophages destroy the host immune cells by engulfing the leukocytes and their precursor cells [31]. sHLH has been a rare disease which associated with genetic, neoplastic, autoimmune, and infectious diseases. However, the different features of sHLH including high fever, abnormal hepatic enzyme levels, cytopenia, and high level of cytokine such as interleukin IL-2, IL-7, GCSF, IP10, MIP1A and TNF- $\alpha$ have been associated with COVID-19 severity [32]. The mechanism of immune and inflammatory response caused by sHLH is still unknown, Thus, further studies are needed to elucidate details of sHLH about immune and inflammatory response to SARS-CoV-2 infection and Kidney injury.

\section{SARS-CoV-2 and Antibody dependent enhancement}

Antibody production plays a vital role in clearing the intruders in the cells, but, the antibody dependent enhancement (ADE) improves its entry into host cells and 
ameliorates its infectivity and virulence. ADE has been reported in SARS-CoV, and feline infectious peritonitis virus (FIPV) where monoclonal antibody Ab binds to the cell surface IgG Fc receptor, which later facilitates the virus to enter inside immune cells [33]. A recent report documents that the Ebola virus stimulates the antibody to bind to its glycoprotein and followed with the complement $\mathrm{C} 1$ which binds to the Fc part of the antibody leading to the enhancement of the virus using endocytosis or receptors of the target cells [34]. Similar study shows that the antigens of MERS bind to an antibody which allows the virus to use its IgG Fc receptors to enter these immune cells [35]. ADE may eventually distribute this virus to other parts the host cells end up with AKI and multi-organs failure. Therefore, ADE can mediate immune responses and induces inflammatory responses, lymphopenia and cytokine storm. However, the role of ADE in SARS-CoV-2 pathogenesis and the molecular mechanism is not well-known. This should be clarified in the future in order to assess the safety of SARS-COV-2 vaccine and inaugurate proper strategies for new emerges infection in the future.

\section{SARS-CoV-2 and Complement system}

The complement system eliminates the viruses by different mechanisms, including a direct neutralization of cell-free virus, destruction of virus-cell infected, and urges the specific immune response. The uncontrolled of complement activation can mediate autoimmune and severe inflammatory responses [36].

It has been reported that $\mathrm{N}$ proteins of SARS-CoV, MERS-CoV interacts with MASP2 , a regulatory protein in the lectin pathway of complement activation, resulting high inflammatory responses and abnormal complement C5 activation and then induces lung cell injury [37]. A recent study shows the role of complement activation in mediating acute respiratory failure-associated with SARS-CoV-2 [38]. No significant cytopathic effects were observed while the deposition of C5b-9, C4d and MASP-2 appeared [39]. In addition, it has been reported that the autopsy from COVI-19 patients shows a microangiopathy and microvascular coagulation which can be induced by complement activation. Moreover, the C5b-9 concentration is high in the AKI patient compared to the patient without AKI [40].

SARS-CoV-2 infection can activate complement system to induce kidney injury by classical, alternative, and lectin pathways. However, a renin which has enzymatic activity on the complement C3 can split it into C3a and C3b due to a positive feedback from unregulated RAS components (Fig. 2) [41]. Moreover, complement C5b-9 deposition forms a lytic pole in the outer membrane of kidney cells, then release proinflammatory cytokines, vasoactive chemicals, and reactive oxygen species which will contribute to the pathogenesis of AKI [42]. It has been also reported that C5a can induce pro-inflammatory chemokines produced with neutrophils dependent or independent pathways to mediate renal injury $[43,44]$. Several antibodies, peptide, RNA interference are being used to block the complement molecules. Interestingly, complement inhibitor like Eculizumab showed to be effective in the treatment of COVID-19 [45].

Taken together, the immune systems perform an incomparable role in fighting against an intruder like SARS-CoV-2. The involvement and intercommunication between innate and adaptive immunity recruit the immune cells and produce different cytokines in a regulated manner. The immune responses and inflammatory cytokines are coordinated by the complement cascade activation. However, hyper-stimulation of the immune responses and accompanied with camouflaged virus may result in host cell injury and correlate with AKI and multi-organs failure. Therefore, more clarification on the complement system and immune responses in general with their impact on the kidney will be highlighted in the future. 


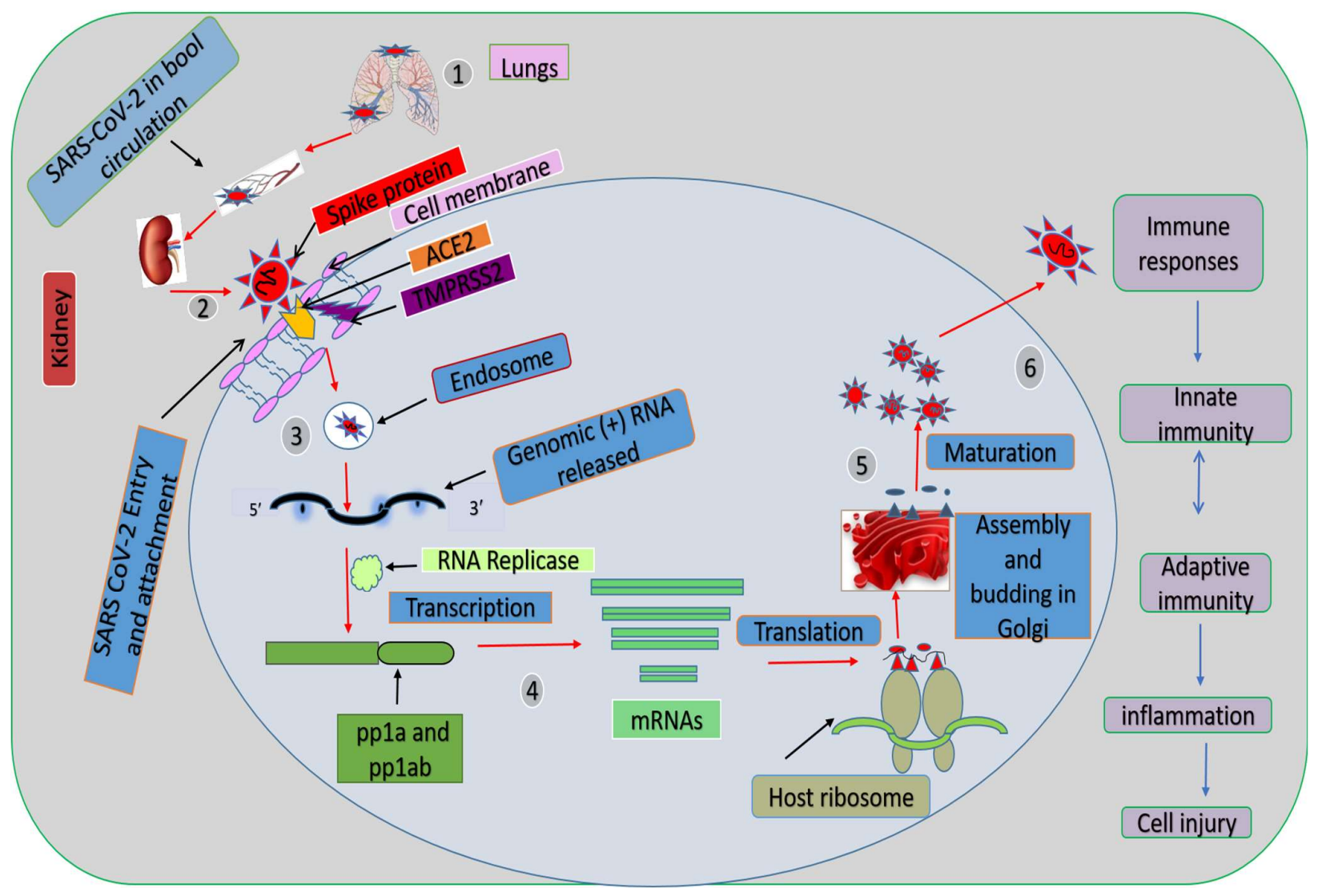

Figure 1. SARS-CoV-2 pathogenesis and AKI.

SARS-CoV-2 pathogenesis and AKI: SARS-CoV-2 invades host cells by using upper airways, reaching to the lungs. The virus can circulate in the blood reaching to different organs including kidney. Inside the host cells, SARS-CoV-2 undergoes its cycle replication resulting in the cell lysis. In this time, more immune response can be produced resulting in the systemic inflammation due to cytokine storm.

\section{Immune response and SARS-CoV-2: Renin-angiotensin system and AKI}

Renin - angiotensin system (RAS) is known to regulate the fundamental processes of cardiovascular homeostasis such as balancing blood pressure, body fluid, electrolyte, and maintaining the vascular tone. It starts with juxtaglomerular apparatus in macula densa of the kidney which detects the decline in renal blood flow and then converts prorenin by neuroendocrine convertase 1 into renin enzyme [46]. Renin converts angiotensinogen into angiotensin I, which is then converted to Ang II by angiotensin converting enzyme (ACE). ACE2 is a type I transmembrane glycoprotein belongs to the zinc-dependent metallopeptidases in the metzincins superfamily which cleaves an amino acids group of the Ang II to form angiotensin-(1-7) thence weakening its effects on vasoconstriction and sodium $(\mathrm{INa}+)$ reabsorption [47]. On the other hand, Ang II stimulates the production of AntiDiuretic Hormone (ADH) and aldosterone hormone thereby mediating the reabsorption of water and $\mathrm{Na}+$ respectively, leading to the constriction of blood vessels and elevation of blood pressure and extracellular body fluid [48]. The main question is if RAS is involving in the SARS-CoV-2 pathogenesis. A recent report has shown the association between a reduced serum $\mathrm{Na}+$ concentration and the severity COVID-19 [49]. A similar study shows the mean differences of $\mathrm{Na}+$ concentrations in critical COVID-19 patients having $136.6 \mathrm{mmol} / \mathrm{L}$ whereas in mild patients having $139.2 \mathrm{mmol} / \mathrm{L}$ [50]. These reports reveal the pathophysiology of SARS-CoV-2 in interacting with RAS components and changing the 
normal physiology of the kidney organ leading to the severity of the disease. We propose that SARS-CoV-2 can crosstalk with RAS components in mediating immune response resulting in kidney impairment. Therefore, it is paramount to review the role of RAS components in regulating the immune response, including the production of different cytokines.

RAS components have been shown to mediate the immune responses by promoting the inflammatory mediator production (Fig.2). For instance, Ang II mediates pro-inflammatory responses by controlling a transcription factor, nuclear factor-kappa B (NF- $\kappa \mathrm{B}$ ) and produces different cytokines including TNF- $\alpha$, IL-1, IL-6, ICAM, VCAM-1, MCP-1, MMP-1, MMP-9, TGF- $\beta$, and AP-1. In addition, Ang II can also promote renal injury by changing the stability of helper T-cell (Th), producing the interferon- $\gamma$, and reducing the IL-4 level [51]. Moreover, angiotensin-(1-7) enhances vasodilatation by increasing nitric oxide bioavailability via Mas oncogene receptor. The nitric oxide plays a role in regulation and activation of the immune and inflammatory mediators, including $\mathrm{T}$ lymphocytes, macrophages, natural killer cells, mast cells and neutrophils [52]. The role of RAS components in mediating AKI has been documented where COVID-19 patients with AKI had the increased plasma RAS components compared to the patients without AKI as shown in Table 2.

SARS-CoV-2 enters the cells by using ACE2 where it may end up with a reduced ACE2 and promotes the raise of a pro-inflammatory mediators Ang II, and imbalance of RAS components, which will eventually trigger the immune responses, complement activation, and impairment of different organs including kidney. However, the molecular mechanism of RAS in mediating the immune response induced by SARS-CoV-2 remains uncertain. Therefore, more studies are highly needed to explore the interaction and regulation of systemic inflammation mediated by the crosstalk of RAS and SARS-CoV-2. More understanding of this mechanism can open a new look of how to tackle this health threat.

Table 2. Role of RAS components in mediating AKI.

\begin{tabular}{|c|c|c|c|}
\hline $\begin{array}{l}\text { Methodology of the } \\
\text { study }\end{array}$ & Results & Conclusion & Reference \\
\hline $\begin{array}{l}\text { COVID-19 patients } \\
\text { with AKI admitted to } \\
\text { the ICU of St Louis } \\
\text { Hospital were screened } \\
\text { the levels of plasma } \\
\text { Renin and aldosterone }\end{array}$ & $\begin{array}{l}\text { Patients with AKI had } \\
\text { an increased level of } \\
\text { renin and aldosterone } \\
\text { compare to patients } \\
\text { without AKI }\end{array}$ & $\begin{array}{c}\text { Activation of RAS is } \\
\text { linked with AKI in } \\
\text { COVID-19 }\end{array}$ & $\begin{array}{c}\text { (Dudoignon et al., } \\
\text { 2020) [56] }\end{array}$ \\
\hline $\begin{array}{c}\text { Non diabetic and } \\
\text { induced diabetic rat } \\
\text { were subjected to AKI, } \\
\text { and then treated with an } \\
\text { AT2R agonist, C21, } \\
\text { ACE2 activator }\end{array}$ & $\begin{array}{c}\text { Plasma ACE, AT2R, } \\
\text { Ang II were increased, } \\
\text { while ACE2, Ang-(1-7) } \\
\text { were reduced followed } \\
\text { by renal injury }\end{array}$ & $\begin{array}{l}\text { AT2R and ACE, and } \\
\text { Ang II can mediate } \\
\text { AKI }\end{array}$ & $\begin{array}{c}\text { (Sharma et al., 2019) } \\
{[57]}\end{array}$ \\
\hline $\begin{array}{l}\text { To determine the role of } \\
\text { Ang II AT1R in } \\
\text { Malaria-induced AKI, } \\
\text { C57BL/6 mice were } \\
\text { infected with } \\
\text { Plasmodium berghei } \\
\text { ANKA (PbA) and } \\
\text { control mice treated } \\
\text { with losartan } \\
\text { ( antagonist of AT1R) } \\
\text { and captopril } \\
\text { (antagonist of ACE) }\end{array}$ & $\begin{array}{l}\text { The high levels of } \\
\text { plasma creatinine and } \\
\text { blood urea nitrogen } \\
\text { were associated with a } \\
\text { reduction in creatinine } \\
\text { clearance, and } \\
\text { glomerular hyper- } \\
\text { cellularity, he high } \\
\text { proteinuria and collagen } \\
\text { deposition and } \\
\text { interstitial space and } \\
\text { was associated with } \\
\text { pro-inflammatory } \\
\text { cytokines were }\end{array}$ & $\begin{array}{l}\text { Ang II/AT1R mediates } \\
\text { an elevation of pro- } \\
\text { inflammatory cytokines } \\
\text { which in turn leads to } \\
\text { AKI }\end{array}$ & (Silva et al., 2018) [58] \\
\hline
\end{tabular}




\begin{tabular}{|c|c|}
\hline $\begin{array}{c}\text { observed in } \mathrm{PbA} \\
\text { infected mice compared } \\
\text { to the control mice }\end{array}$ & \\
\hline $\begin{array}{l}\text { To determine the role of } \\
\text { Ang-(1-7) in kidney Ang-(1-7) treatment } \\
\text { injury, Col4a3 -/- mice diminish the production } \\
\text { used as albert syndrome of inflammatory } \\
\text { model and treated with cytokines and adhesion } \\
\text { Ang-(1-7) while wild molecules and apoptosis } \\
\text { mice type treated with reduced in kidney cells } \\
\text { saline }\end{array}$ & $\begin{array}{l}\text { Ang-(1-7) reduces } \\
\text { kidney injury in Alport (Choi et al., 2020) [59] } \\
\text { syndrome experimental }\end{array}$ \\
\hline
\end{tabular}

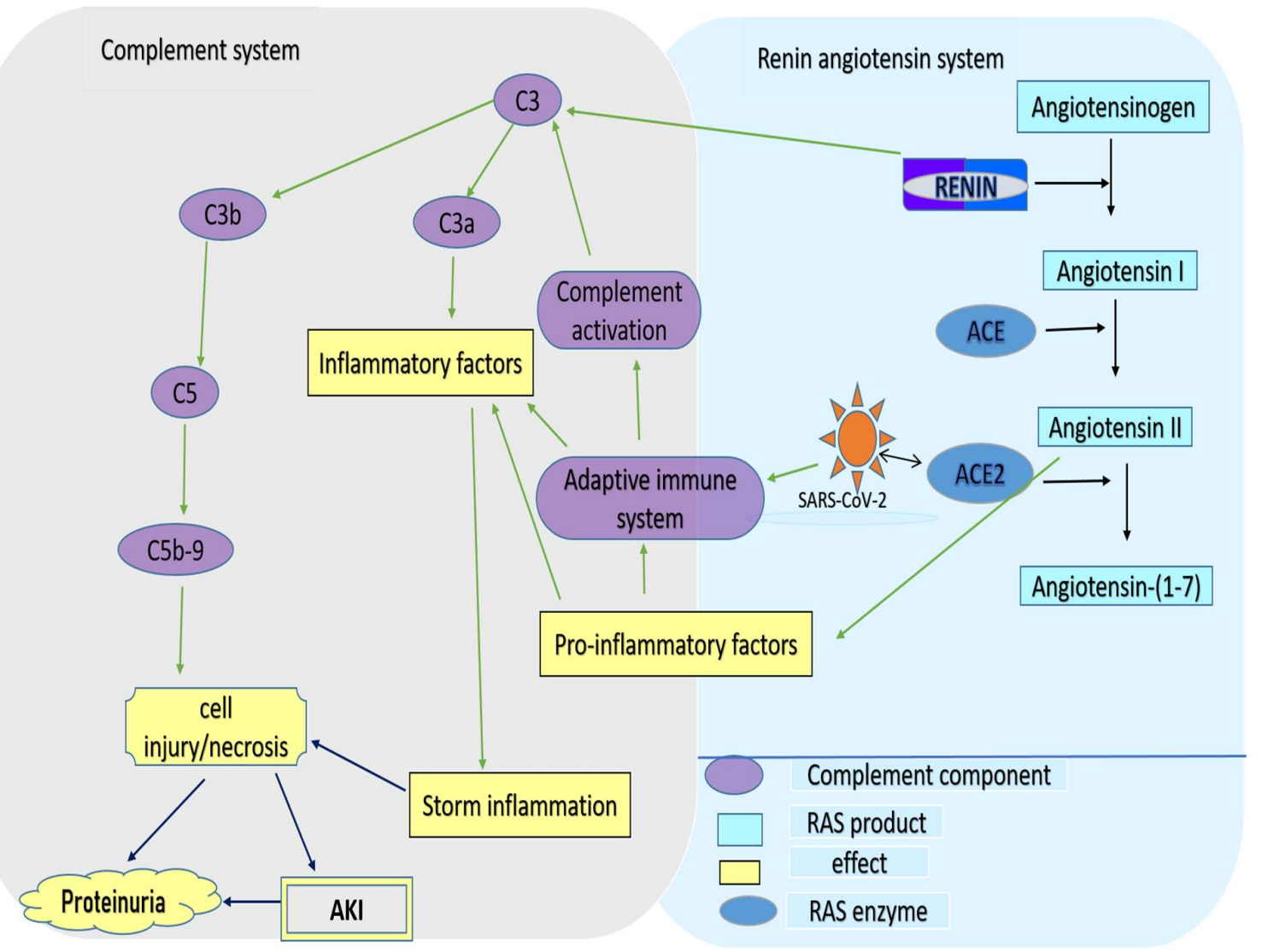

Figure 2. Interaction of RAS and immune responses.

Interaction of RAS and immune responses: SARS-CoV-2 uses ACE2 as its receptor, infected cell can trigger complement cascade activated or stimulate immune response which can recruit complement system to participate in clearing an intruder. Complement activation can be activated by renin enzyme due to positive feedback from using RAS enzyme inhibitors where all these pathways may come together to mediate storm inflammation, cell injury and multi-organ failure.

\section{Conclusion and prospects}

SARS-CoV-2 which causes COVID-19 binds to ACE 2 with its spikes to invade the cells. It first colonizes upper and lower respiratory. It may trigger the production of cytokines and immune responses which can affect the remaining organs where multi-organs impairment can increase morbidity and mortality. Another possibility is that circulating ACE2 can spread the virus to infect other organs apart from respiratory organs. Kidney impairment is primarily caused by indirect interactions with immune responses, but 
maybe the viruses enter the kidney cells contributing to the injury, even if it is not exposed to the virus as compared to the lungs. Since its discovery, a number of studies have been done to reveal the pathogenesis of SARS-CoV-2 in different organs, where patients with critically COVID-19 exhibit a high level of pro-inflammatory mediators, which correlate with the severity of disease leading to the high mortality rate induced by AKI. Both immune response and unbalance RAS components mediated SARS-CoV-2 can promote the overstimulation of the pro-inflammatory factors which may result in organ failure, particularly kidney damage. However, several challenges have been appeared. First, the extent of acute kidney injury mediated by the immune response, viral toxicity or multifarious engagements due to SARS-CoV-2 remains uncertain. Second, the role of complement activation and its inhibitors for managing AKI and multi-organs failure during SARSCoV-2 infection still need more clarifications. Third, the contribution of RAS to activate the cytokines production in the SARS-CoV-2 infection remains unclear. Therefore, there are many solutions to be documented in the future. Further research is needed to elucidate the mechanism of kidney impairment caused by SARS-CoV-2. To understand the mechanism and crosstalk between SARS-CoV-2, RAS, and immune response can help to establish new strategies for controlling the current threat and new emerging infection in the future.

\section{Abbreviations}

ACE2: Angiotensin converting enzyme 2

ACEIs: Angiotensin-converting enzyme inhibitors

ADE: Antibody Dependent Enhancement

AKI: Acute kidney injury

Ang II: Angiotensin II

ARBs: Angiotensin II receptor blockers

AT1/2: Angiotensin receptor type $1 / 2$

AP-1: Activator Protein-1

COVID-19: Coronavirus disease 2019

CRP: C-reactive protein

DAI: DNA-dependent activator of interferon-regulatory factors

FIPV: Feline Infectious Peritonitis Virus

GSCF: Granulocyte Stimulating Colony Factor

ICAM: Intercellular Adhesion Molecule

IP-10: Interferon gamma-induced protein 10

IL: Interleukin

IRAKs: Interleukin-1 Receptor Associated Kinases

MASP-2: Mannose-binding protein-associated serine protease-2

MMP: Matrix Metalloproteinases

MAC: Membrane Attack Complex

MDA5: Melanoma Differentiation-Associated Protein 5

MERS-CoV: Middle East Respiratory Syndrome Coronavirus

MCP-1: Monocyte Chemoattractant Protein-1

MIG: Monokine induced by gamma interferon

MyD88: Myeloid Differentiation primary response 88

NADH: Nicotinamide Adenine Dinucleotide Dehydrogenase

NADPH: Nicotinamide Adenine Dinucleotide Phosphate

NO: Nitric Oxide

Nsp: nonstructural protein

NF- $\kappa$ B: nuclear Factor-kappa B

ORF: Open reading frame

PAMP: Pathogen-Associated Molecular Patterns

PRR: Pattern-Recognition Receptors

PHEIC: Public Health Emergency of International Concern 


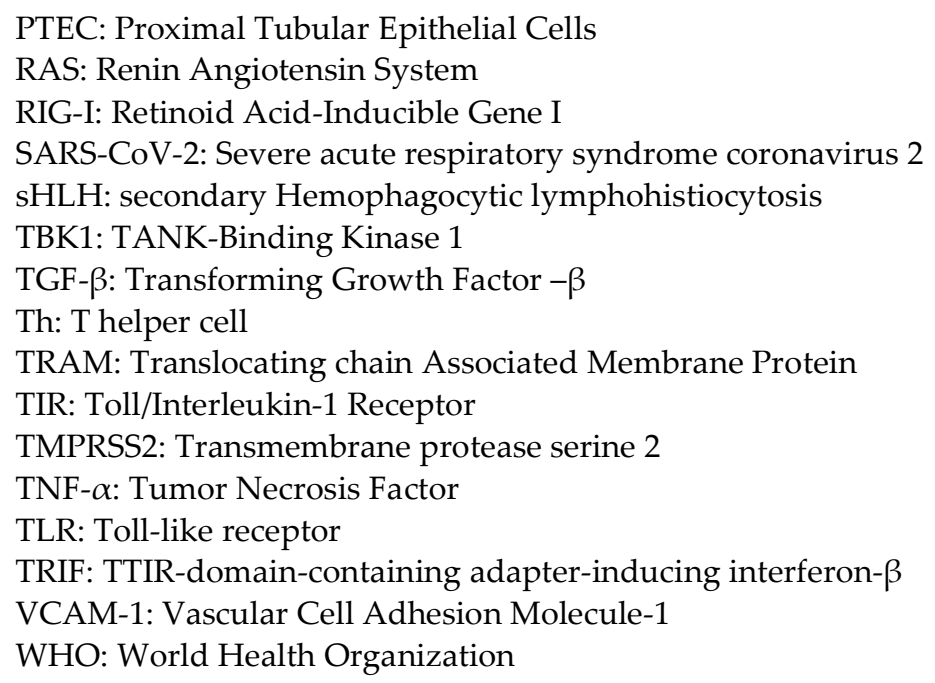

Ethical approval and consent to participate: Not applicable.

Consent for publication: Not applicable.

Availability of supporting data: Not applicable.

Competing for interest: We declare that we have no conflicts of interest.

Funding: This work was supported by the National Natural Science Foundation of China (31501701).

Authors' contribution: Bernard Nsengimana collected the data, and prepared the manuscript. Wen-
qiang Wei conceived and supervised the review. Bernard Nsengimana, Yu Jin, Yuting Jia organized
the manuscript. Shaoping Ji revised this review. All authors read and approved the final manu-
script.

Acknowledgments: This work is supported by the National Natural Science Foundation of China (No.31371386). The authors appreciate all the scientists whose works contribute to this review article. We also apologize to scientists whose works were not included in this review due to space constriction.

\section{References}

1. Guo, J., Wei, X., Li, Q., Li, L., Yang, Z., 2020. Single - cell RNA analysis on ACE2 expression provides insights into SARS - CoV - 2 potential entry into the bloodstream and heart injury. J. Cell. phyisiology 1-11. https://doi.org/10.1002/jcp.29802

2. Gopalakrishnan, A., Mossaid, A., Lo, K.B., Vasudevan, V., Mccullough, P.A., Rangaswami, J., 2020. Fulminant Acute Kidney Injury in a Young Patient with Novel Coronavirus 11201, 1-6. https://doi.org/10.1159/000508179

3. Wichmann, D., Sperhake, J.-P., Lütgehetmann, M., Steurer, S., Edler, C., Heinemann, A., Heinrich, F., Mushumba, H., Kniep, I., Schröder, A.S., Burdelski, C., de Heer, G., Nierhaus, A., Frings, D., Pfefferle, S., Becker, H., Bredereke-Wiedling, H., de Weerth, A., Paschen, H.-R., Sheikhzadeh-Eggers, S., Stang, A., Schmiedel, S., Bokemeyer, C., Addo, M.M., Aepfelbacher, M., Püschel, K., Kluge, S., 2020. Autopsy Findings and Venous Thromboembolism in Patients With COVID-19. Ann. Intern. Med. https://doi.org/10.7326/m20-2003

4. Oikonomopoulou, K., Ricklin, D., Ward, P.A., Lambris, J.D., 2012. Interactions between coagulation and complement - Their role in inflammation. Semin. Immunopathol. https://doi.org/10.1007/s00281-011-0280-x

5. Michael, B., Giuseppe, H., Henry, B.M., 2020. Chronic kidney disease is associated with severe coronavirus disease 2019 ( COVID - 19 ) infection. Int. Urol. Nephrol. 2019, 9-10. https://doi.org/10.1007/s11255-020-02451-9

6. Yichun Cheng1, 2, , Ran Luo1, 2, , Kun Wang1, 2, Zhang1, M., Wang1, Z., Dong1, L., Li1, J., Yao1, Y., Xu1, S.G. and G., 2020. Kidney disease is associated with in-hospital death of patients with COVID-19. https://doi.org/10.1016/j.kint.2020.03.005

7. Gabarre, P., Dumas, G., Dupont, T., Darmon, M., Azoulay, E., Zafrani, L., 2020. Acute kidney injury in critically ill patients with COVID-19. Intensive Care Med. 46, 1339-1348. https://doi.org/10.1007/s00134-020-06153-9

8. Hazzan, A.D., Fishbane, S., Jhaveri, K.D., 2020. Acute kidney injury in patients hospitalized with COVID-19 209-218. https://doi.org/10.1016/j.kint.2020.05.006

9. Fominskiy, E. V., Scandroglio, A.M., Monti, G., Calabrò, M.G., Landoni, G., Dell'Acqua, A., Beretta, L., Moizo, E., Ravizza, A., 
Monaco, F., Campochiaro, C., Pieri, M., Azzolini, M.L., Borghi, G., Crivellari, M., Conte, C., Mattioli, C., Silvani, P., Mucci, M., Turi, S., Tentori, S., Baiardo Redaelli, M., Sartorelli, M., Angelillo, P., Belletti, A., Nardelli, P., Nisi, F.G., Valsecchi, G., Barberio, C., Ciceri, F., Serpa Neto, A., Dagna, L., Bellomo, R., Zangrillo, A., 2020. Prevalence, Characteristics, Risk Factors, and Outcomes of Invasively Ventilated COVID-19 Patients with Acute Kidney Injury and Renal Replacement Therapy. Blood Purif. 1-8. https://doi.org/10.1159/000508657

10. Sun, J., Zhu, A., Li, H., Zheng, K., Zhuang, Z., Chen, Z., Shi, Y., Zhang, Z., Chen, S. bei, Liu, X., Dai, J., Li, X., Huang, S., Huang, X., Luo, L., Wen, L., Zhuo, J., Li, Yuming, Wang, Y., Zhang, L., Zhang, Y., Li, F., Feng, L., Chen, X., Zhong, N., Yang, Z., Huang, J., Zhao, J., Li, Yi min, 2020. Isolation of infectious SARS-CoV-2 from urine of a COVID-19 patient. Emerg. Microbes Infect. 9 , 991-993. https://doi.org/10.1080/22221751.2020.1760144

11. Su, H., Yang, M., Wan, C., Yi, L.-X., Tang, F., Zhu, H.-Y., Yi, F., Yang, H.-C., Fogo, A.B., Nie, X., Zhang, C., 2020. Renal histopathological analysis of 26 postmortem findings of patients with COVID-19 in China. Kidney Int. 98, $219-227$. https://doi.org/10.1016/j.kint.2020.04.003

12. Kudose, S., Batal, I., Santoriello, D., Xu, K., Barasch, J., Peleg, Y., Canetta, P., Ratner, L.E., Marasa, M., Gharavi, A.G., Stokes, M.B., Markowitz, G.S., D’Agati, V.D., 2020. Kidney Biopsy Findings in Patients with COVID-19. J. Am. Soc. Nephrol. ASN.2020060802. https://doi.org/10.1681/asn.2020060802

13. Sharma, P., Uppal, N., Wanchoo, R., Shah, H., Yang, Y., Parikh, R., Khanin, Y., Madireddy, V., Larsen, C., Jhaveri, K., Bijol, V., 2020. COVID-19-Associated Kidney Injury: A Case Series of Kidney Biopsy Findings. J. Am. Soc. Nephrol. ASN.2020050699. https://doi.org/10.1681/ASN.2020050699

14. Yan, H., Xiao, G., Zhang, J., Hu, Y., Yuan, F., Cole, D.K., Zheng, C., Gao, G.F., 2004. SARS coronavirus induces apoptosis in Vero E6 Cells. J. Med. Virol. 73, 323-331. https://doi.org/10.1002/jmv.20094

15. Schifanella, A.L., Anderson, J.L., Galli, M., Corbellino, M., Lai, A., Wieking, G., Grzywacz, B., Klatt, N.R., Haase, A.T., Schacker, T.W., 2020. Massive viral replication and cytopathic effects in early COVID-19 pneumonia.

16. Abbate, M., Rottoli, D., Gianatti, A., 2020. COVID-19 Attacks the Kidney: Ultrastructural Evidence for the Presence of Virus in the Glomerular Epithelium. Nephron 144, 341-342. https://doi.org/10.1159/000508430

17. Tripathi, Parul, Tripathi, Prashant, Kashyap, L., Singh, V., 2007. The role of nitric oxide in inflammatory reactions. FEMS Immunol. Med. Microbiol. 51, 443-452. https://doi.org/10.1111/j.1574-695X.2007.00329.x

18. Lim, K.H., Staudt, L.M., 2013. Toll-Like receptor signaling. Cold Spring Harb. Perspect. Biol. 5. https://doi.org/10.1101/cshperspect.a011247

19. Vyncke, L., Bovijn, C., Pauwels, E., Van Acker, T., Ruyssinck, E., Burg, E., Tavernier, J., Peelman, F., 2016. Reconstructing the TIR Side of the Myddosome: A Paradigm for TIR-TIR Interactions. Structure 24, 437-447. https://doi.org/10.1016/j.str.2015.12.018

20. Totura, A.L., Whitmore, A., Agnihothram, S., Schäfer, A., Katze, M.G., Heise, M.T., Baric, R.S., 2015. Toll-like receptor 3 signaling via TRIF contributes to a protective innate immune response to severe acute respiratory syndrome coronavirus infection. MBio 6, 1-14. https://doi.org/10.1128/mBio.00638-15

21. Wang, Y.M., Ji, R., Chen, W.W., Huang, S.W., Zheng, Y.J., Yang, Z.T., Qu, H.P., Chen, H., Mao, E.Q., Chen, Y., Chen, E.Z., 2019. Paclitaxel alleviated sepsis-induced acute lung injury by activating MUC1 and suppressing TLR-4/NF- $\kappa$ B pathway. Drug Des. Devel. Ther. 13, 3391-3404. https://doi.org/10.2147/DDDT.S222296

22. Dosch, S.F., Mahajan, S.D., Collins, A.R., 2009. SARS coronavirus spike protein-induced innate immune response occurs via activation of the NF- $\mathrm{B}$ pathway in human monocyte macrophages in vitro. Virus Res. 142, 19-27. https://doi.org/10.1016/j.virusres.2009.01.005

23. Azkur, A.K., Akdis, M., Azkur, D., Sokolowska, M., Veen, W., Brüggen, M., O’Mahony, L., Gao, Y., Nadeau, K., Akdis, C.A., 2020. Immune response to SARS-CoV-2 and mechanisms of immunopathological changes in COVID-19. Allergy 75, $1564-1581$. https://doi.org/10.1111/all.14364

24. Zhao, Q., Meng, M., Kumar, R., Wu, Y., Huang, J., Deng, Y., Weng, Z., Yang, L., 2020. Lymphopenia is associated with severe coronavirus disease 2019 ( COVID-19) infections: A systemic review and meta-analysis. Int. J. Infect. Dis. 96, 131-135. https://doi.org/10.1016/j.ijid.2020.04.086

25. Biasi, S. De, Meschiari, M., Gibellini, L., Bellinazzi, C., Borella, R., Fidanza, L., Gozzi, L., Iannone, A., Tartaro, D. Lo, Mattioli, M., Paolini, A., Menozzi, M., Mili, J., Franceschi, G., Fantini, R., Tonelli, R., Sita, M., Sarti, M., Trenti, T., Brugioni, L., Cicchetti, L., Facchinetti, F., Pietrangelo, A., Clini, E., Girardis, M., Guaraldi, G., Mussini, C., Cossarizza, A., 2020. Marked T cell activation, senescence, exhaustion and skewing towards TH17 in patients with COVID-19 pneumonia 1-17. https://doi.org/10.1038/s41467$\underline{020-17292-4}$

26. Huang, C., Wang, Y., Li, X., Ren, L., Zhao, J., Hu, Y., Zhang, L., Fan, G., Xu, J., Gu, X., 2020a. Clinical features of patients infected with 2019 novel coronavirus in Wuhan, China 6736, 1-10. https://doi.org/10.1016/S0140-6736(20)30183-5

27. Duque, G.A., Descoteaux, A., 2014. Macrophage cytokines: Involvement in immunity and infectious diseases. Front. Immunol. https://doi.org/10.3389/fimmu.2014.00491

28. Moledina DG, Mansour SG, Jia Y, Thiessen-philbrook H, Koyner JL, Mcarthur E, et al. Association of T cell-derived Inflammatory Cytokines with Acute Kidney Injury and Mortality after Cardiac Surgery Cohort. Kidney Int Reports [Internet]. 2019; Available from: https://doi.org/10.1016/j.ekir.2019.09.003 
29. Winkles, J.A., Lorz, C., Egido, J., Ortiz, A., 2006. Cytokine cooperation in renal tubular cell injury: The role of TWEAK 17501758. https://doi.org/10.1038/sj.ki.5001866

30. Zhang, C., Wu, Z., Li, J., Zhao, H., Wang, G., 2020. International Journal of Antimicrobial Agents Cytokine release syndrome in severe COVID-19: interleukin-6 receptor antagonist tocilizumab may be the key to reduce mortality 55. https://doi.org/10.1016/j.ijantimicag.2020.105954

31. Cameron, M.J., Ran, L., Xu, L., Danesh, A., Bermejo-Martin, J.F., Cameron, C.M., Muller, M.P., Gold, W.L., Richardson, S.E., Poutanen, S.M., Willey, B.M., DeVries, M.E., Fang, Y., Seneviratne, C., Bosinger, S.E., Persad, D., Wilkinson, P., Greller, L.D., Somogyi, R., Humar, A., Keshavjee, S., Louie, M., Loeb, M.B., Brunton, J., McGeer, A.J., Kelvin, D.J., 2007. Interferon-Mediated Immunopathological Events Are Associated with Atypical Innate and Adaptive Immune Responses in Patients with Severe Acute Respiratory Syndrome. J. Virol. 81, 8692-8706. https://doi.org/10.1128/jvi.00527-07

32. Hoepel, W., Chen, H.-J., Allahverdiyeva, S., Manz, X., Aman, J., Bonta, P., Brouwer, P., de Taeye, S., Caniels, T., van der Straten, K., Golebski, K., Griffith, G., Jonkers, R., Larsen, M., Linty, F., Neele, A., Nouta, J., van Baarle, F., van Drunen, C., Vlaar, A., de Bree, G., Sanders, R., Willemsen, L., Wuhrer, M., Bogaard, H.J., van Gils, M., Vidarsson, G., de Winther, M., den Dunnen, J., 2020. Anti-SARS-CoV-2 IgG from severely ill COVID-19 patients promotes macrophage hyper-inflammatory responses. bioRxiv 2020.07.13.190140. https://doi.org/10.1101/2020.07.13.190140.

33. Filipovich, A.H., 2009. Hemophagocytic lymphohistiocytosis (HLH) and related disorders 127-131. https://doi.org/https://doi.org/10.1182/asheducation-2009.1.127

34. Henderson, L.A., Canna, S.W., Schulert, G.S., Volpi, S., Lee, P.Y., Kernan, K.F., Caricchio, R., Mahmud, S., Hazen, M.M., Halyabar, O., Hoyt, K.J., Han, J., Grom, A.A., Gattorno, M., Ravelli, A., Benedetti, F., Behrens, E.M., Cron, R.Q., Nigrovic, P.A., 2020. On the Alert for Cytokine Storm: Immunopathology in $<$ scp $>$ COVID $</$ scp $>-19$. Arthritis Rheumatol. 72, $1059-1063$. https://doi.org/10.1002/art.41285

35. Perlman, S., Dandekar, A.A., 2005. Immunopathogenesis of coronavirus infections: Implications for SARS. Nat. Rev. Immunol. https://doi.org/10.1038/nri1732

36. Takada, A., Feldmann, H., Ksiazek, T.G., Kawaoka, Y., 2003. Antibody-Dependent Enhancement of Ebola Virus Infection 77, 7539-7544. https://doi.org/10.1128/JVI.77.13.7539

37. Wan, Y., Shang, J., Sun, S., Tai, W., Chen, J., Geng, Q., He, L., Chen, Y., Wu, J., Shi, Z., Zhou, Y., Du, L., Li, F., 2019. Molecular Mechanism for Antibody-Dependent Enhancement of Coronavirus Entry. J. Virol. 94, $2015-2034$. https://doi.org/10.1128/jvi.02015-19

38. Noris, M., Remuzzi, G., 2013. Overview of complement activation and regulation. Semin. Nephrol. 33, 479-492. https://doi.org/10.1016/j.semnephrol.2013.08.001

39. Gao, A.T., Hu, M., Zhang, X., Li, H., Zhu, L., 2020. Highly pathogenic coronavirus N protein aggravates lung injury by MASP2- mediated complement over-activation. https://doi.org/10.1101/2020.03.29.20041962

40. Magro C, Mulvey JJ, Berlin D, Nuovo G, Salvatore S, Harp J, et al. Complement associated microvascular injury and thrombosis in the pathogenesis of severe COVID-19 infection: A report of five cases. 2020;220:1-13. Available from: https://doi.org/10.1016/j.trsl.2020.04.007

41. Noris, M., Benigni, A., Remuzzi, G., 2020. The case of complement activation in COVID-19 multiorgan impact. Kidney Int. https://doi.org/10.1016/j.kint.2020.05.013

42. Danobeitia, J.S., Ziemelis, M., Ma, X., Zitur, L.J., Zens, T., Chlebeck, J., Amersfoort, E.S. Van, Fernandez, L.A., 2017. Complement inhibition attenuates acute kidney injury after ischemia-reperfusion and limits progression to renal fibrosis in mice 1-20. https://doi.org/10.1371/journal.one.018370

43. Xiao, H., Schreiber, A., Heeringa, P., Falk, R.J., Jennette, J.C., 2007. Alternative Complement Pathway in the Pathogenesis of Disease Mediated by Anti- Neutrophil Cytoplasmic Autoantibodies 170, 52-64. https://doi.org/10.2353/ajpath.2007.060573

44. Vries, B. De, Köhl, J., Leclercq, W.K.G., Tim, G.A., Wolfs, M., Bijnen, A.A.J.H.M. Van, Heeringa, P., Buurman, W.A., Vries, B. De, 2020. Complement Factor C5a Mediates Renal Ischemia-Reperfusion Injury Independent from Neutrophils. https://doi.org/10.4049/jimmunol.170.7.3883

45. Nakano, D., Nishiyama, A., 2018. A novel role of renin inhibitor in the complement cascade. Kidney Int. $94,650-652$. https://doi.org/10.1016/j.kint.2018.05.025

46. Wysocki, J., González-Pacheco, F.R., Batlle, D., 2008. Angiotensin-converting enzyme 2: Possible role in hypertension and kidney disease. Curr. Hypertens. Rep. 10, 70-77. https://doi.org/10.1007/s11906-008-0014-1

47. Cerdà-Costa, N., Gomis-Rüth, F.X., 2014. Architecture and function of metallopeptidase catalytic domains. Protein Sci. 23, 123144. https://doi.org/10.1002/pro.2400

48. Patel, S., Rauf, A., Khan, H., Abu-Izneid, T., 2017. Renin-angiotensin-aldosterone (RAAS): The ubiquitous system for homeostasis and pathologies. Biomed. Pharmacother. 94, 317-325. https://doi.org/10.1016/j.biopha.2017.07.091

49. Post, A., Dullaart, R.P.F., Bakker, S.J.L., 2020. Sodium status and kidney involvement during COVID-19 infection. Virus Res. 286, 198034. https://doi.org/10.1016/j.virusres.2020.198034

50. Luo, Y., Li, Y., Dai, J., 2020. Low blood sodium increases risk and severity of COVID-19 : a systematic review , meta-analysis and retrospective cohort study. https://doi.org/doi.org/10.1101/2020.05.18.20102509 
51. Tham, D.M., Martin-McNulty, B., Wang, Y.X., Wilson, D.W., Vergona, R., Sullivan, M.E., Dole, W., Rutledge, J.C., 2003. Angiotensin II is associated with activation of NF- $\mathrm{BB}$-mediated genes and downregulation of PPARs. Physiol. Genomics 11, 2130. https://doi.org/10.1152/physiolgenomics.00062.2002

52. Chatterjee, P., Chiasson, V.L., Bounds, K.R., Mitchell, B.M., 2014. Regulation of the Anti-Inflammatory Cytokines Interleukin-4 and Interleukin-10 during Pregnancy. Front. Immunol. 5, 1-1. https://doi.org/10.3389/fimmu.2014.00253

53. Wu, Y., Huang, X., Sun, J., Xie, T., Lei, Y., Muhammad, J., Li, X., Zeng, X., Zhou, F., 2020. crossm Clinical Characteristics and Immune Injury Mechanisms in 71 Patients with COVID-19 5, 1-11. https://doi.org/10.1128/mSphere.00362-20

54. Chen G, Zhao J, Ning Q, Chen G, Wu D, Guo W, et al. Clinical and immunological features of severe and moderate coronavirus disease 2019 Clinical and immunological features of severe and moderate coronavirus disease 2019. 2020;130(5):2620-9. 29. https://doi.org/10.1172/JCI137244

55. Yang, Y., Shen, C., Li, J., Yuan, J., Yang, M., Wang, F., Li, G., Li, Y., Xing, L., Peng, L., Wei, J., Cao, M., Zheng, H., Wu, W., Zou, R., Li, D., Xu, Z., Wang, H., Zhang, M., Zhang, Z., Liu, L., Liu, Y., 2020. Exuberant elevation of IP-10, MCP-3 and IL-1ra during SARS-CoV-2 infection is associated with disease severity and fatal outcome 2019. https://doi.org/10.1101/2020.03.02.20029975

56. Dudoignon, E., Moreno, N., Deniau, B., Coutrot, M., Longer, R., Amiot, Q., Mebazaa, A., Pirracchio, R., Depret, F., Legrand, M., 2020. Activation of the Renin-angiotensin-aldosterone system is associated with Acute Kidney injury in COVID-19. Anaesth. Crit. Care Pain Med. https://doi.org/10.1016/j.accpm.2020.06.006

57. Sharma, N., Malek, V., Mulay, S.R., Gaikwad, A.B., 2019. Angiotensin II type 2 receptor and angiotensin-converting enzyme 2 mediate ischemic renal injury in diabetic and non-diabetic rats. Life Sci. 235, 116796. https://doi.org/10.1016/j.lfs.2019.116796

58. Silva, L.S., Peruchetti, D.B., Silva-Aguiar, R.P., Abreu, T.P., Dal-Cheri, B.K.A., Takiya, C.M., Souza, M.C., Henriques, M.G., Pinheiro, A.A.S., Caruso-Neves, C., 2018. The angiotensin II/AT1 receptor pathway mediates malaria-induced acute kidney injury. PLoS One 13, 7-9. https://doi.org/10.1371/journal.pone.0203836

59. Choi, H.S., Kim, I.J., Kim, C.S., Ma, S.K., Scholey, J.W., Kim, S.W., Bae, E.H., 2020. Angiotensin-[1-7] attenuates kidney injury in experimental Alport syndrome. Sci. Rep. 10, 1-11. https://doi.org/10.1038/s41598-020-61250-5

60. Xu, X., Yu, M., Shen, Q., Wang, L., Yan, R., Zhang, M., Liu, J., 2020. Analysis of inflammatory parameters and disease severity for 88 hospitalized COVID-19 patients in 17. https://doi.org/10.7150/ijms.47935 